\title{
Timber frames as an earthquake resisting system in Portugal
}

\author{
E. Poletti, G. Vasconcelos \& P.B. Lourenço \\ ISISE, Faculty of Engineering, University of Minho, Guimarães, Portugal
}

\begin{abstract}
Timber frames are commonly adopted as a structural element in many countries with specific characteristics varying locally, in terms of geometry and materials. Their diffusion in Southern European countries is linked to their good seismic-resistant capacity, but only in the last decade interest has grown for this structural typology, and studies have been performed to better understand their behaviour. In this contribution, a brief state of the art on existing timber frame building typologies is presented, focusing on their seismic-resistant characteristics. Additionally, an overview of possible strengthening solutions, adopted both in practice, and tested experimentally are presented. Their performance when applied to walls and connections is also discussed.
\end{abstract}

\section{INTRODUCTION}

Timber frame buildings are a common traditional construction present in many countries, particularly in local vernacular architecture, as they constitute an important cultural heritage worth preserving. They are characterised by a timber frame, which in some cases presents bracing members, filled with different infill materials such as earth mortar, canes, masonry. Portuguese Pombalino buildings represent a valuable construction typology, both for their cultural significance after the 1755 's Lisbon earthquake and the creation of a new city, as well as for the introduction of new and innovative technological features. In fact, it is in this period that timber frame construction developed as an effective seismic-resistant system in regions of high seismicity, such as Southern European countries.

\section{TIMBER FRAMES AS A LOCAL CONSTRUCTION SYSTEM}

\subsection{Diffusion of the system}

Timber frames have been adopted worldwide for centuries. The first timber frames date back to more than 2000 years, as testified by Vitruvius, who in his De architectura describes the so-called Opus Craticium. It evolved from wattle and daub construction and it used for the first time squared structural timber elements and a more resistant infill (Ulrich, 2007). This kind of construction has evolved along the centuries as joinery got more sophisticated, craftsmanship improved, and the availability of wood changed in different countries.

In each country, a great variability exists in terms of geometry and materials, as the type of frame was influenced by local traditions, and tendency for this cheap construction was to build with local materials.
The availability of wood and the length of the elements dictated the geometry of the frame. Infill was also based on the available materials and could vary from wooden planks, to skin, to wattle and daub, to earth mortar and to bricks.

Examples of timber framed construction can be found all over Europe, in North and South America, and in Asia. In England, timber frame construction evolved with the adoption of curved elements, and from the XV century the use of close studding and decorative panels, to show off the owners' wealth, (Fig. 1) became common. After the great fire of London, this type of construction was viewed with scepticism, but it was later adopted for upper storeys in revival houses from the XIX century. In Germany, fachwerk construction can be found all over the country, and later emigrants took this tradition with them when they left the country for the USA, or for Eastern European countries. Commonly to other central European countries, timber frame buildings (colombages) were introduced in France during the Middle Ages and were used until the XIX century. The buildings evolved from frames adopting long timbers, to frames adopting shorter timbers, with a lighter and stiffer structure, and the introduction of jetties. The French exported too their know-how abroad, and examples deriving from colombages construction can be found in Haiti and the USA.

Similarly, in Turkey, hımış construction is a very common vernacular construction, usually with a timber-laced masonry ground floor (hatll). Different infill typologies were adopting, such as rubble masonry, lath and plaster (bağdadi) and wooden planks (dizeme). Other examples of timber frame construction can be found in Kashmir (dhajji-dewari), Peru (quincha), Nicaragua (taquezal), El Salvador (bahareque), just to name a few (Langenbach, 2007). For more information on timber frame construction worldwide, see Poletti (2013). 


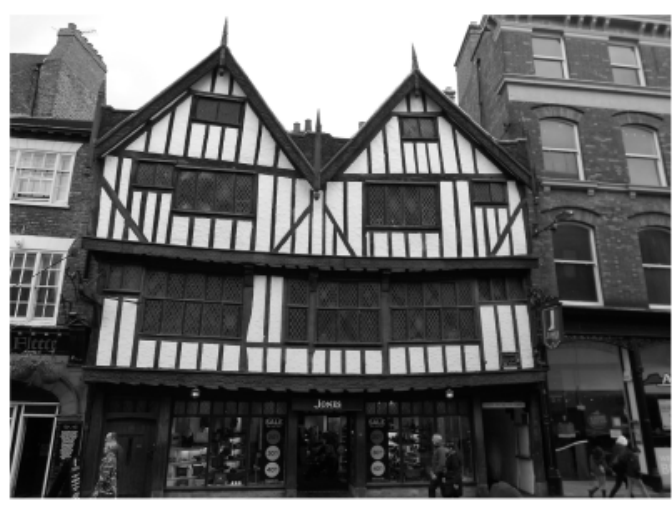

Figure 1. A XV century timber frame house in York, England (credits: E. Poletti).

\subsection{Earthquake-resistant solution}

Past earthquakes have shown the good seismic properties of timber frame structures, when compared to other construction present in the territory. As a result, timber frames have been specifically adopted in the past as a seismic-resistant solution. This is particularly true for Portugal, Italy and Greece, where timber frames were adopted in regulations and codes (in Italy, the first ever seismic code was drawn up suggesting the use of the Borbone system).

In Italy, after the 1783 earthquake that destroyed Reggio Calabria, a new system, called casa baraccata (literally, 'baracca' means shack) was adopted by the authorities, by imposing standardized construction methods. The same construction technique, with slight changes, was also adopted after the Messina earthquake in 1908. The government (at the time, the Bourbon dynasty was ruling in the south of Italy) appointed engineers to develop rules for the reconstruction of the region. In 1784, the Royal Instructions ("Istruzioni Reali") were emanated, and they consisted of rules to be applied to the new buildings. The rules included instructions on the exterior aspect of the buildings, on the height of buildings, on the width of streets, rules on construction of balconies, on domes and bell towers; and on the addition of an internal timber skeleton. These rules constituted the first official norms for seismic design.

Even though timber framing was already common in Calabria, a standardised type of half-timbered building was introduced by Giovanni Vivenzio, the court's physicist. This choice was born by the observation of the good seismic behaviour of existing half-timbered buildings, such as the palace of Nocera, built in 1638 (Bianco, 2010). Vivenzio proposed a 3-storey building with a timber skeleton, aiming at reinforcing the external masonry walls, avoiding their premature outof-plane collapse (Figure 2.7b). The timber frames constituted the shear walls, presenting a bracing system of S. Andrew's cross, similar to what can be found in Lisbon (Tobriner, 1997). This system was

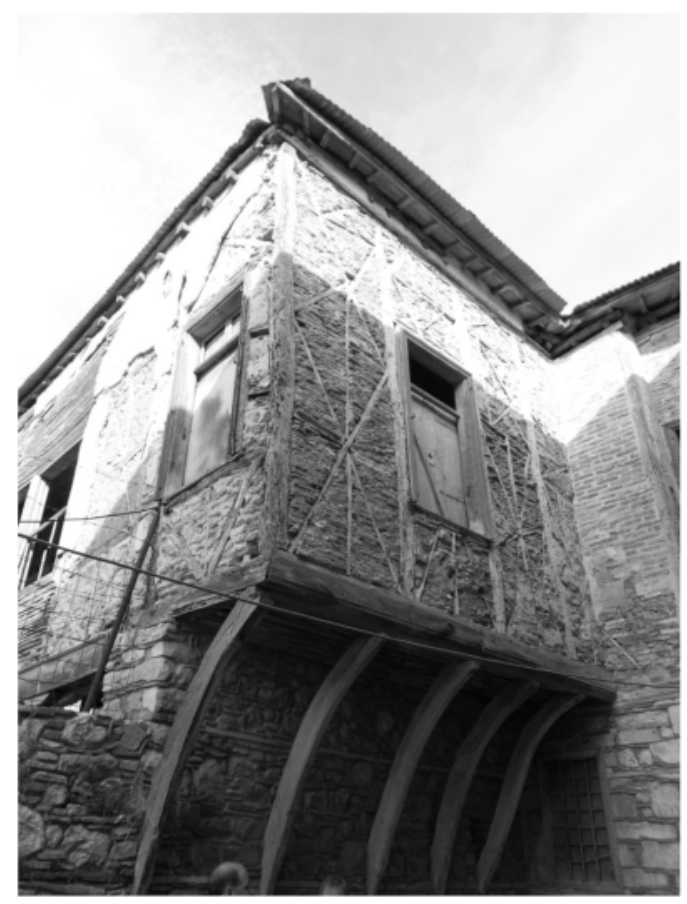

Figure 2. A traditional timber frame house in Chalkida, Greece (credits: E. Poletti).

also adopted for exterior walls in this type of buildings. Similarly to the Portuguese example, Vivenzio also proposed a construction by blocks, in this case of three buildings. The idea is that the central building has a higher height, and the lateral ones act as buttresses. This disposition allows for symmetry in the two directions, ensuring a similar stiffness for both directions. Different dispositions were adopted for the timber frame, from a double bonded frame with masonry in the middle (used for public buildings) to a single frame embedded into the wall at different depths (Ruggieri et al., 2015).

Other important earthquakes that affected the south of Italy occurred in Messina in 1905 and in 1908, during which the casa baraccata system showed a good seismic resistance (Rugieri et al., 2014). Nonetheless, after these events, the new standards of 1909 included rules for foundations. The standards suggested to prepare the foundation ground with a foundation slab and carry out diggings if necessary. Rock foundations or a firm soil are preferred. Moreover the posts had to be well fixed to the stone or to the foundation slab for at least $80 \mathrm{~cm}$. They should be burned at the extremities to prevent decay (Bianco, 2010).

Another country that uses timber frame buildings as a seismic-resistant solution is Greece. Half-timbered buildings were common all over Greece in different periods, as reported by many authors (Vintzileou et al., 2007; Tsakanika, 2008). Examples of this system are the monastic buildings in Meteora and Mount Athos, 
the post byzantine (Ottoman period) buildings in Central and Northern Greece; and the traditional buildings in the island of Lefkas.

Timber has been used together with masonry in Greece since the Minoan period (Tsakanika, 2008). This constructive solution evolved from the use of only horizontal timber elements to tie masonry, and to prevent the propagation of cracks to a heavier timber frame, adopting both vertical and horizontal timber members to reinforce masonry.

The half-timbered buildings in the island of Lefkas are different from those present in other regions of Greece. Here, a local structural system was developed before the 19th century. It demonstrated to be able to sustain seismic actions after buildings, built with this system, had showed a good seismic performance during the earthquake of 1821 (Vintzileou et al., 2007). During the same earthquake, the existing masonry buildings collapsed. Based on this, British Authorities (which ruled the Ionian Islands at the time) imposed new rules, developed from the aforementioned local system (Code of construction, issued in 1827) (Vintzileou et al., 2007). The rules provided guidance on the selection of building materials, thickness of stone masonry walls (at the ground floor), storey height and distance between adjacent buildings, similarly to what happened in Portugal and Italy. An innovation present in these buildings is the existence, at the ground floor, of timber columns stiffened by angles that constituted a secondary load bearing system in case of failure of the masonry walls, since they were connected to the timber-framed structure of the upper storeys (Vintzileou et al., 2007).

These buildings proved to be able to efficiently resist to earthquakes in 2003, when the island was hit by a strong quake. The main damages observed were not only due to this latest earthquake but also to previous ones, and the decay was due to poor maintenance. Additionally, modifications done in the existing structure, such as removing the ground masonry walls, led to large permanent horizontal displacements, since the secondary bearing system did not have sufficient stiffness (Vintzileou et al., 2007). In fact, the damages observed were sometimes due to poor or no maintenance, and to modifications done to the buildings, pointing out the importance of preservation. But timber frame buildings are present all over Greece. Usually consist of a timber-tied ground floor, and timber-framed upper storeys (see Fig. 2).

But even in countries where this system was not standardised, this structural typology has proven its very good seismic-resistant capacity. Of course, all observations should be taken with caution, since they depend on the level of maintenance of the traditional timber frame structures analysed. In Turkey, for example, after the big earthquakes that hit Kocaeli and Duzce in 1999, reports show that, in many regions, well-preserved traditional timber frame houses suffered less severe damage when compared to reinforced concrete and masonry structures (Gülhan \& Güney, 2000). Similar reports also came in after the earthquakes in India and Peru. Because of their good performance, timber frame buildings have been used for reconstruction plans of vernacular buildings in rural areas hit by catastrophes, such as Haiti and Pakistan.

\section{PORTUGUESE TIMBER FRAMES TRADITION}

\subsection{Lisbon area}

After the devastating earthquake in 1755 that destroyed Lisbon Downtown, a reconstruction plan was put into action by the Prime Minister of the time, Marquis of Pombal, who appointed engineers and military architects to elaborate reconstruction plans of the city. The new regulations adopted provided rules for urban, architectonical and structural design, such as minimal distances between buildings, typology of façades, width of roads and sidewalks, height of the buildings, orientation of the buildings, structural system and creation of blocks (Mascarenhas, 2004). The new buildings designed took into account the seismic capacity of the structure, safety against fire, as well as a standardization of the structural elements, in order to achieve a cheaper and faster construction.

The buildings that derived from the proposed plan, called Pombalino buildings, were characterised by external masonry walls and an internal timber structure, named gaiola (cage), which is a three dimensional braced timber structure, similar to many half-timbered buildings that can be found in several European countries. The gaiola consists of horizontal and vertical elements, and diagonal bracing members, forming the typical X of St. Andrew's crosses (Fig. 3), which have a dissipative function (Cóias, 2007). The timber frame walls are usually filled, either with rubble or brick masonry, or even earth mortar and hay. Plaster was applied to frontal walls, creating small cuts in the timber elements so that mortar, generally lime-based, could adhere better. The adoption of a weak mortar and infill allowed flexibility to the wall joints, which could dissipate a higher amount of energy in case of an earthquake.

The ground floor consists of stone masonry columns supporting stone arches and vaults made of clay bricks, above which, in the first floor, the gaiola develops, reaching up to 5 storeys. This solution was adopted in order to prevent fire propagation to the upper floors. Early Pombalino buildings had a constant width of the stone walls of the façade, while in earlier or later buildings the width decreases along the height (Mascarenhas, 2004). The typical width of the external masonry walls was of $90 \mathrm{~cm}$ at the ground floor. A simplified internal timber structure was embedded into the external masonry walls on the inner side, to facilitate and to improve the connections with the floors, and the inner timber frame walls. The connections between the external masonry walls and the internal timber frame walls varied and it depended mainly on the number and 


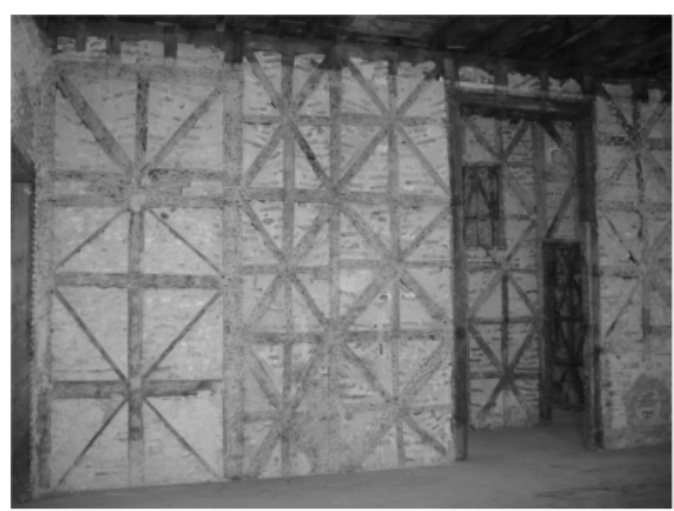

Figure 3. Internal timber frame walls in a Pombalino building (credits: MONUMENTA).

length of timber elements embedded in the external walls (Moreira et al., 2014).

Additionally, masonry walls perpendicular to the façades divided the buildings and avoided fire propagation in adjacent buildings.

This construction typology was not completely new to Lisbon, as in the oldest parts of the city, near the Castle; a similar simplified construction can be found. The innovation consists of the improvement of the system, as well as the standardization of the constructive practice in Lisbon (Mascarenhas, 2004).

The internal walls of the gaiola (frontal walls) may have different geometries in terms of cell dimensions and number of elements, as it depended greatly on the available space and the manufacturer's practices. The timber elements are notched together or connected by nails or metal ties. Traditional connections used for the timber elements varied significantly in the buildings: the most common ones were mortise and tenon, half-lap and dovetail connections. Variability exists in the sectional dimensions of the elements themselves: the diagonal members are usually smaller $(10 \times 10 \mathrm{~cm}$ or $10 \times 8 \mathrm{~cm}$ ), whilst the vertical posts and horizontal members are bigger (usually $12 \times 10,12 \times 15 \mathrm{~cm}$ and $14 \times 10 \mathrm{~cm}$ or $15 \times 13,10 \times 13$ and $10 \times 10 \mathrm{~cm}$ respectively). The thickness of frontal walls can vary from 15 to $20 \mathrm{~cm}$ (Mascarenhas, 2004; Cóias, 2007).

The peculiarity of this type of buildings is that under a seismic event it is admissible that the heavy masonry of the façades falls down, as well as the tiles of the roof, and the plaster of the inner walls, but the timber skeleton should remain intact, assuring the resistance of the timber floors and keeping the building standing (Mascarenhas, 2004).

The Pombalino timber frame walls were built to provide an adequate resistance to seismic loading. However, it should be pointed out that their seismic efficiency has never been tested under onsite real conditions, as no other great earthquake has hit Lisbon since their construction. A number of experimental studies exist proving the good seismic resistance potential of Pombalino walls (Meireles, 2012; Poletti \& Vasconcelos, 2015).

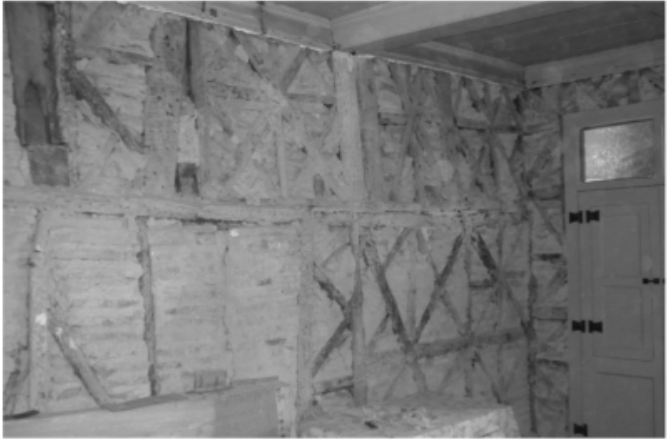

Figure 4. Timber frame walls in a traditional house in Guimarães (credits: E. Poletti).

Approximately a hundred years after the earthquake the building practice changed, getting worse from a seismic point of view. Pombalino buildings, where a complete gaiola structure is present and it is expected to be efficient against seismic actions, were progressively replaced by Gaioleiro buildings, where the timber structure does not exist and therefore structurally represent a worse construction quality (Mendes \& Lourenço, 2010).

\subsection{Other Pombalino developments}

After the beginning of the reconstruction of Lisbon, other similar developments were created in locations of the country that were thought to have a strategic position and a potential for economic growth.

Vila Real de Santo Antonio in Algarve was redesigned in 1773 by military engineers, who follow plans similar to those adopted for the reconstruction of Lisbon.

Similarly, Porto Côvo in Alentejo was financed by a merchant, to transform a small fishing village into a trading centre (Mascarenhas, 2004). The interesting point is that the existing traditional houses were adapted to the organized scheme introduced by the Pombalino construction.

\subsection{Northern regions}

Pombalino-type constructions can also be found in medieval city centres in the north of the country, for example in Porto, Vila Real, Chaves, Braga and Guimarães, even if the seismic hazard is very low in these locations. Their construction dates back to the XV-XVII centuries adopting a traditional halftimbered wall typology (taipa de rodizio). The ground floor consisted of stone masonry, typically granite, while in the upper storeys the external walls were half-timbered, adopting diagonal bracing members. The internal walls were either half-timbered or partition timber walls, typically lath and plaster walls (taipa de fasquio). Sometimes, apart from brick and rubble masonry, hay was used as infill. Considering the elements dimensions, in the buildings surveyed in 
Guimarães, the posts and main beams had a width of $15 \mathrm{~cm}$, while the diagonals and the secondary elements of $7 \mathrm{~cm}$ (Fig. 4). Taipa de rodizio was typically adopted for bourgeois houses, while noble houses had external walls built in granite and timber frames were only used for internal walls (Ferrão \& Afonso, 2001).

\section{APPROPRIATENESS OF RETROFITTING TECHNIQUES}

Timber frame buildings constitute an important portion of many historical city centres in the world. Many of these buildings have known little or no care during their life, or they have been modified without taking into account the seismic response of the structure after the alterations had been made. Indeed, a common and extremely invasive practice has been the demolition of the inner part of the building, which is substituted by a reinforced concrete one, keeping only the original masonry façades (Cóias, 2007), therefore actually losing the original timber frame structure.

Following good practices, and as the result of the neglect of these constructive elements and their consequent progressive decay, namely at the connections, it has been often decided to retrofit these structures. Here, a brief summary of strengthening techniques adopted and their efficiency is presented.

\subsection{In-situ applications}

Many examples are available on restoration works done in traditional half-timbered buildings (Cóias, 2007; Appleton \& Domingos, 2009). Numerous Pombalino buildings in Lisbon have been retrofitted using FRP sheets in the connections of the frontal walls (Cóias, 2007), or damping systems linking to frontal walls and to the outer masonry walls through injected anchors and providing additional bracing (Figure 5) (Cóias, 2007). Another practice is to project reinforced shortcrete onto the timber frame walls (Appleton \& Domingos, 2009), but such a solution could effectively have an overly stiffening effect on the joints.

\subsection{Experimental solutions}

Various strengthening techniques have been tested experimentally specifically for Pombalino timber frame walls (Gonçalves et al., 2012; Poletti et al., 2014; Poletti et al., 2015). From previous experimental studies (Meireles, 2012; Poletti \& Vasconcelos, 2015) it was seen that the cyclic behaviour of timber frame walls depends mainly on the response of the connections. Therefore, strengthening should be concentrated at the location of the connections.

Strengthening with steel plates (Figure 6) led to an increase in strength and stiffness of the wall, also greatly improving its dissipative capacity (Gonçalves, 2012; Poletti et al., 2014). When linking the diagonals to the main frame through the plates, some out-ofplane problems were encountered, as the connections

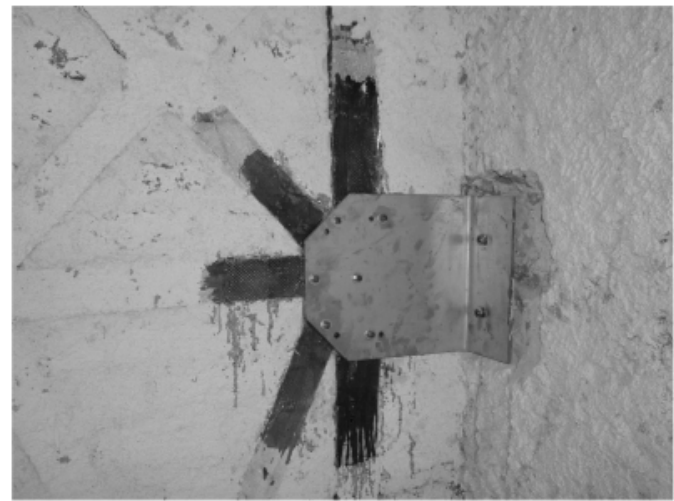

Figure 5. Timber frame to masonry wall connection by means of injected anchors and steel plate (credits: MONUMENTA).

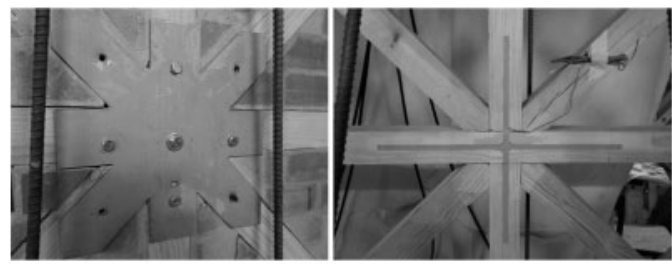

Figure 6. Steel plates strengthening (left) and NSM bars (right) (credits: E. Poletti).

were greatly stiffened when compared to the original configuration. This problem was overcome by not connecting the bracing elements to the plate, but leaving the original connection intact (Poletti et al., 2014). Steel plates led to an increase of the lateral capacity of the walls between $50 \%$ and $200 \%$, also improving their post-peak behaviour. This technique is simple to implement and it is removable.

Near-Surface-Mounted (NSM) steel flat bars were also applied to the connections (Figure 6) and tests showed a good response in terms of stiffness and energy dissipation, particularly for weak infill (Poletti et al., 2015). Additionally, this technique is potentially invisible, even though not removable.

Tests performed on walls, on which reinforced render was applied on both sides (Gonçalves et al., 2012), showed that this solution greatly increases the stiffness of the walls, not taking advantage of the dissipative capacity of the connections.

Another possible strengthening solution consists of an elasto-plastic steel damper acting along the diagonal of the wall (Gonçalves et al., 2012). This solution showed a good dissipative capacity when the damper was in tension, while buckling was observed when in compression, therefore leading to a problematic application in practice.

Other examples of retrofitting techniques applied mainly at the connections with great potential are Glass Fibber Reinforced Polymer (GFRP) sheets, as well as 
a simple solution, such as the adoption of self-tapping screws (Poletti, 2013).

\section{CONCLUSIONS}

This chapter presents a brief state of the art of timber frame buildings, particularly when specifically built for their seismic-resistance capacity. In Portugal, this typology has been specifically adopted for the reconstruction of Lisbon, due to its large deformation capacity with limited damage.

Timber frame buildings have shown a good seismic response in recent events worldwide, and have been chosen for the reconstruction of rural areas.

An important aspect is that, for them to achieve their full potential, they have to be preserved and well maintained. Therefore, interventions have to be well thought out. They should improve the behaviour of the building without overly altering its original structure. Some of the interventions described here, such as steel plates and NSM bats, are believed to be appropriate techniques for timber frame walls, while others need further research.

\section{REFERENCES}

Appleton, J. \& Domingos, I. (2009). Biografia de um Pombalino. Um caso de reabilitação na Baixa de Lisboa. Editora ORION, Lisbon

Bianco A. (2010). La casa baraccata. Guida al progetto e al cantiere di restauro. Rome, Italy: GBeditoria.

Cóias, V. (2007). Reabilitação estrutural de edificios antigos. Lisbon: ARGUMENTUM, GECoPRA

Ferrão, B., Afonso, J.F. (2001). A evolução da forma urbana de Guimarães e a criação do seu patrimonio edificado. Guimarães: Câmara Municipal de Guimarães.

Gonçalves, A., Ferreira, J., Guerreiro, L. \& Branco F. (2012, September). Seismic retrofitting of Pombalino "frontal" walls. 15th World Conference on Earthquake Engineering, Lisbon.

Gülhan, D. \& Güney I.Ö. (2000). The behaviour of traditional building systems against earthquake and its comparison to reinforced concrete frame systems: experiences of Marmara earthquake damage assessment studies in Kocaeli and Sakarya. Proceedings of Earthquake-safe: Lessons to be Learned from Traditional Construction, Istanbul, Turkey.
Langenbach, R. (2007). From "Opus Craticium" to the "Chicago Frame": Earthquake-Resistant Traditional Construction. International Journal of Architectural Heritage, 1(1), 29-59.

Mascarenhas, J. (2004). Sistemas de Construção-V. Lisbon, Portugal: Livros Horizonte.

Meireles, H.A. (2012). Seismic vulnerability of pombalino buildings, (PhD Thesis, IST Instituto Superior Técnico, Lisbon, Portugal).

Mendes, N. \& Lourenço, P.B. (2010). Seismic assessment of masonry "Gaioleiro" buildings in Lisbon, Portugal. Journal of Earthquake Engineering, 14: 80-101.

Moreira, S., Ramos, L.F., Oliveira, D.V. \& Lourenço, P.B. (2014). Experimental behavior of masonry wall-totimber elements connections strengthened with injection anchors. Engineering Structures, 81, 98-109.

Poletti, E. (2013). Characterization of the seismic behaviour of traditional timber frame walls (PhD Thesis, University of Minho, Guimarães, Portugal).

Poletti, E. \& Vasconcelos, G. (2015). Seismic behaviour of traditional timber frame walls: experimental results on unreinforced walls. Bulleting of Earthquake Engineering, 13, 885-916.

Poletti, E., Vasconcelos, G. \& Jorge, M. (2014). Full-Scale Experimental Testing of Retrofitting Techniques in Portuguese "Pombalino" Traditional Timber Frame Walls. Journal of Earthquake Engineering, 18, 553-579.

Poletti, E., Vasconcelos, G. \& Jorge, M. (2015). Application of near surface mounted (NSM) strengthening technique to traditional timber frame walls. Construction and Building Materials, 76, 34-50.

Ruggieri, N., Tampone, G. \& Zinno, R. (2015). Inplane vs Out-of-plane "Behaviour" of an Italian Timber Framed System: the Borbone Constructive System. Historical Analysis and Experimental Evaluation. International Journal of Architectural Heritage: Conservation, Analysis, and Restoration. doi: 10.1080/15583058.2015.1041189

Tsakanika-Theohari E. (2008, May). The constructional analysis of timber load bearing systems as a tool for interpreting Aegean Bronze Age architecture. Proceedings of the Symposium 'Bronze Age Architectural Traditions in the Eastern Mediterranean: Diffusion and Diversity', Munich.

Ulrich, R.B. (2007). Roman Woodworking. Yale University Press.

Vintzileou, E., Zagkotsis, A., Repapis, C. \& Zeris Ch. (2007). Seismic behaviour of the historical structural system of the island of Lefkada, Greece. Construction and Building Materials, 21, 225-236. 